\title{
Room temperature aging to guarantee microbiological safety of brazilian artisan Canastra cheese
}

\author{
Maturação em temperatura ambiente como garantia da segurança \\ microbiológica de queijos artesanais brasileiros da Serra da Canastra
}

\author{
Milene Therezinha das DORES ${ }^{1 \star}$, Juliana Escarião da NOBREGA ${ }^{1}$, Célia Lucia de Luces Fortes FERREIRA ${ }^{1}$
}

\begin{abstract}
Canastra cheese is one of the oldest and most traditional cheeses made from raw milk in Brazil. However, this type of practice may have severe consequences for human health. According to the current legislation, any cheese made from raw milk must be aged for at least 60 days. Traditionally, Canastra cheese is consumed after different ripening periods, but consumers usually prefer those that are aged less than eight days. This study aimed to evaluate the effects of physicochemical and microbiological parameters, with emphasis on the pathogenic microbiota regulated by law, on cheese aged at room temperature and under refrigeration. Cheese samples were collected from eight different cheese producers located in the Serra da Canastra region twice a year (rainy and dry seasons) and analyzed with 8, 15, 22, 29, 36, and 64 days of ripening. Room temperature aging effectively reduced pathogens, reaching the total count established by law in 22 days, regardless of the season. However, ripening under refrigeration, it was ineffective in reducing the Staphylococcus aureus counts to the legislation limits, even after 64 days. Therefore, Canastra cheese should be ripened for at least 22 days at room temperature in order to fulfill the safety regulatory limits. Keyword: food safety; cheese; raw milk; Staphylococcus aureus.
\end{abstract}

\section{Resumo}

O queijo Canastra é um dos mais antigos e tradicionais queijos produzidos com leite cru no Brasil, no entanto, sua produção pode gerar consequências graves para a saúde. De acordo com lei vigente no País, o queijo feito com leite cru deve ser submetido a um período mínimo de maturação de 60 dias. Tradicionalmente o queijo canastra é consumido após diferentes períodos de maturação, sendo priorizados pelo consumidor os queijos com menos de 8 dias de fabricação. O objetivo deste estudo foi avaliar a modulação de variáveis físico-químicas e microbiológicas, com ênfase na microbiota patogênica regulamentada por lei, no queijo maturado em temperatura ambiente e sob refrigeração. Amostras de queijos foram coletadas em oito propriedades na região, em dois períodos do ano (chuvoso e seco), e analisadas com 8, 15, 22, 29, 36 e 64 dias de fabricação. A maturação em temperatura ambiente foi decisiva para redução da microbiota patogênica para níveis permitidos em 22 dias, nos dois períodos analisados, ao passo que, sob refrigeração, os níveis de Staphylococcus aureus (espécie limitante) permitidos somente seriam atingidos após 64 dias. Dessa forma, mantendo-se a tradição, o queijo canastra maturado por 22 dias em temperatura ambiente apresenta os requisitos legais de segurança.

Palavras-chave: segurança alimentar; queijos; leite cru; Staphylococcus aureus.

\section{Introduction}

Canastra is a traditional variety of Minas farmhouse cheese produced on small scale by a large number of producers in the Serra da Canastra region located in the state of Minas Gerais, Brazil (Altitude from $637 \mathrm{~m}$ to 1,485 $\mathrm{m}$ above sea level, average temperatures of $22.2^{\circ} \mathrm{C}$, and rainfall of $1,390 \mathrm{~mm}$ ). It is made from raw milk from local herds of dairy cows. It is characterized by the addition of natural endogenous starter to fresh raw milk in order to assist the beginning of the fermentation process. Artisan cheeses have been produced using the same technique since the seventeenth century. Nowadays, in order to keep up the production of this important product, the Brazilian legislation requires some technique adjustments to meet the standards of hygiene and sanitation established. Since it is frequently touched by human hands and produced with raw milk, artisanal Minas cheese can have serious consequences on public health due to the risk of conveying pathogens. Therefore, the Brazilian legislation (BRASIL, 1996) allows the sale of cheese made from raw milk only when it is ripened for 60 days at a temperature above $5{ }^{\circ} \mathrm{C}$. However, this long ripening period affects the sale of the product, both economically, for small producers, and in terms of quality due to changes in the cheese taste. Since the product is usually sold fresh (immediately after it's been manufactured), vacuum-packed, and refrigerated, it does not meet the microbiological standards established by legislation (PINTO et al., 2004).

Few scientific studies have been made to date confirming the role of temperature and aging on the physicochemical and microbiological characteristics of artisanal cheeses produced in the Minas Gerais state (MARTINS, 2006). The knowledge of the effects of aging and temperature on the modulation of pathogenic microorganisms, in addition to the physical and

1 Universidade Federal de Viçosa - UFV, Rod. BR 354, Km 310, CP 22, CEP 38810-000, Rio Paranaíba, MG, Brasil, e-mail: milene.dores@ufv.br ${ }^{*}$ Corresponding author 
chemical characteristics of these cheeses, is necessary in order to guide the adjustments to be made in the production units as well as in producers' training programs and help to bring these products out of informality and clandestinity. This information would also be used to legalize the sale of these products. Without proper definition of ripening time, the artisanal cheese from "Serra da Canastra", a widely consumed and enjoyed product, may pose serious risks to the public health.

This study aimed to evaluate the effect of ripening time on the physicochemical and microbiological parameters, with special emphasis on the pathogenic microbiota regulated by the legislation, on cheese made in the rainy and the dry seasons and aged at room temperature and at refrigeration for a period of 64 days.

\section{Materials and methods}

\subsection{Sample collection and storage}

The Canastra cheese samples were randomly collected from eight production units in two seasons: the rainy season - May 2006 and in the dry season - September 2006. A total of 16 samples were collected in duplicate. The cheese samples were collected two days after manufacturing in order to complete the salting process. The samples were then transported to the ripening chambers located in the Laboratory of Lactic Cultures of Federal University of Viçosa. They were stored either under ambient conditions, at a temperature of $25{ }^{\circ} \mathrm{C}$ and relative humidity $(\mathrm{RH})$ around $68 \%$ in the rainy season and $62 \%$ in the dry season, or under refrigeration, at a temperature of $8{ }^{\circ} \mathrm{C}$ and $\mathrm{RH}$ around $77 \%$ in the rainy season and $75 \%$ in the dry season. The samples were analyzed in the pre-determined times of 8 , $15,22,29,36$ and 64 days of ripening.

\subsection{Physicochemical analysis}

The cheese $\mathrm{pH}$ was determined according to previously described methodology (BRASIL, 1996). Water activity (aw) was determined in a AquaLab CX2 aw meter (Decagon Devices, Inc., Pullman, Wash). The content of sodium chloride was determined according to the method of Pereira et al. (2001).

\subsection{Microbiological analysis}

Twenty five g of cheese were mixed with $225 \mathrm{~mL}$ of $2 \%$ sterile peptone water and then homogenized in a stomacher for 1 minute. Decimal dilutions were made, followed by plating in duplicate for each dilution.

The counts of coliforms and Escherichia coli (E. coli) at $30^{\circ} \mathrm{C}$ were made by using petrifilms (3M Petrifilm ${ }^{\mathrm{TM}} \mathrm{EC}$ method $-3 \mathrm{M}$ Company, St. Paul, MN, EUA). The total count of mesophilic bacteria in the artisanal cheese was determined by the pour plate method in Petri dishes using the culture medium Plate Count Standard Agar - PCA (Merck). After 48 hours, the plates were counted and the results expressed in cfu. $\mathrm{g}^{-1}$ (LANCETTE; BENNET, 2001).

For the analysis of Staphylococcus aureus (S. aureus), 3M Petrifilm $^{\mathrm{TM}}$ RSA (3M Company, St. Paul, MN, EUA) was used in accordance with the procedures established by the manufacturer (PONSANO et al., 2000; SCHÖELLER; INGHAM, 2001).

The Reveal - Salmonella Test System ( ${ }^{\circledR}$ Neogem corporation, USA/Canada) was used in the analysis of Salmonella sp. For the detection of Listeria sp., the Reveal Test for Listeria $\left({ }^{\circledR} \mathrm{Neogem}\right.$ corporation, USA/Canada) was used in accordance with the procedures established by the distributor.

\subsection{Statistical analysis}

The physicochemical and microbiological data were subjected to analysis of variance. When necessary, a regression analysis was performed. The regression coefficients were tested using the t-test at 5\% significance level. All statistical analyses were performed using the Statistical Analysis System (STATISTICAL..., 2003).

\section{Results and discussion}

The microbiological counts and physicochemical values are shown in Figures 1 and 2. According to the results, the physicochemical and microbiological data were significantly influenced $(\mathrm{p}<0.05)$ by the time of ripening, regardless of the season that the cheese was made or the storage temperature (room temperature or refrigerated).

In artisanal cheeses stored under refrigeration, ripening time had no significant effects $(\mathrm{p}<0.05)$ on any of the variables analyzed (Figure 2). This lack of change could be attributed to decreased enzymatic and metabolic reactions of the microorganisms caused by the low temperature.

During aging at room temperature, a decrease in water activity (Aw) was observed. During the rainy season, the water activity was 0.98 at the beginning of the ripening period, and it decreased to 0.93 at the end of the ripening period. For the dry season, water activity started at 0.98 and decreased to 0.92 in the end of the ripening period. The values of Aw of cheese stored under refrigeration remained at 0.98 for the entire ripening period in both seasons.

The values of sodium chloride $(\mathrm{NaCl})$ increased during aging at room temperature. The salt content increased from 1.43 to $2.47 \% \mathrm{NaCl}$ in the rainy season and from 1.50 to $2.74 \%$ in the dry season. Under refrigeration, this variation was lower, ranging from 1.49 to $1.69 \% \mathrm{NaCl}$ in the rainy season and from 1.55 to $1.76 \% \mathrm{NaCl}$ in dry season. It is important to point out that the chloride content of the different cheeses is fairly irregular due to the salting technique used (MARTINS, 2006).

An increasing $\mathrm{pH}$ trend was observed during ripening; no change was as high as that observed at room temperature in the dry season (Figure 1). The increase in $\mathrm{pH}$ may be related to protein degradation due to activity of a natural milk protease (plasmin) and the proteases present in the endogenous starter resulting in the formation of alkaline nitrogenous compounds. Deamination and proteolysis that occur in the decarboxylation of amino acids and dissociation of acids, mainly lactic acid, are factors that contribute to the increase in $\mathrm{pH}$ (KOSIKOWSKI; MISTRY, 1997; KONGO et al., 2007). 

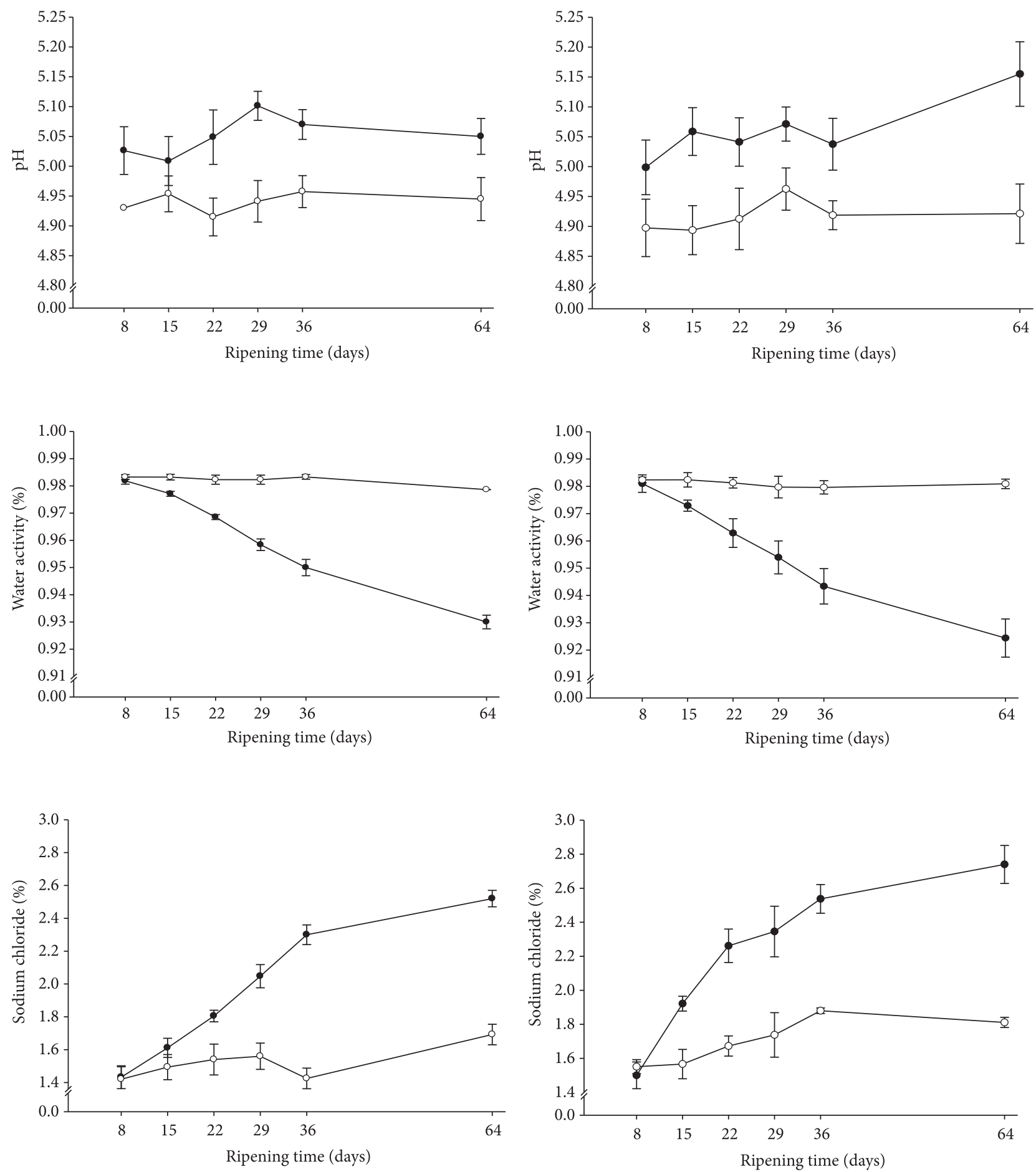

Figure 1. pH, water activity, and sodium chloride of Canastra cheese as a function of ripening time at room temperature (•) and under refrigeration $(\mathrm{O})$ in the dry season and rainy season.

The development of the microbial groups was monitored during ripening (Figure 2). Room temperature and ripening time caused a linear effect on total aerobic counts, coliforms at $30{ }^{\circ} \mathrm{C}$, E. coli and S. aureus. This effect was also observed under refrigeration conditions, although at lower rate.
The presence of Listeria sp. and Salmonella sp. was not detected in any of the samples, even though they are commonly detected in cheese made with raw milk (MORGAN et al., 2001; PAK et al. 2002; VITAS; AGUADO; GARCIA-JALON, 2004; PINTO, 2008; MARTINS, 2006). 

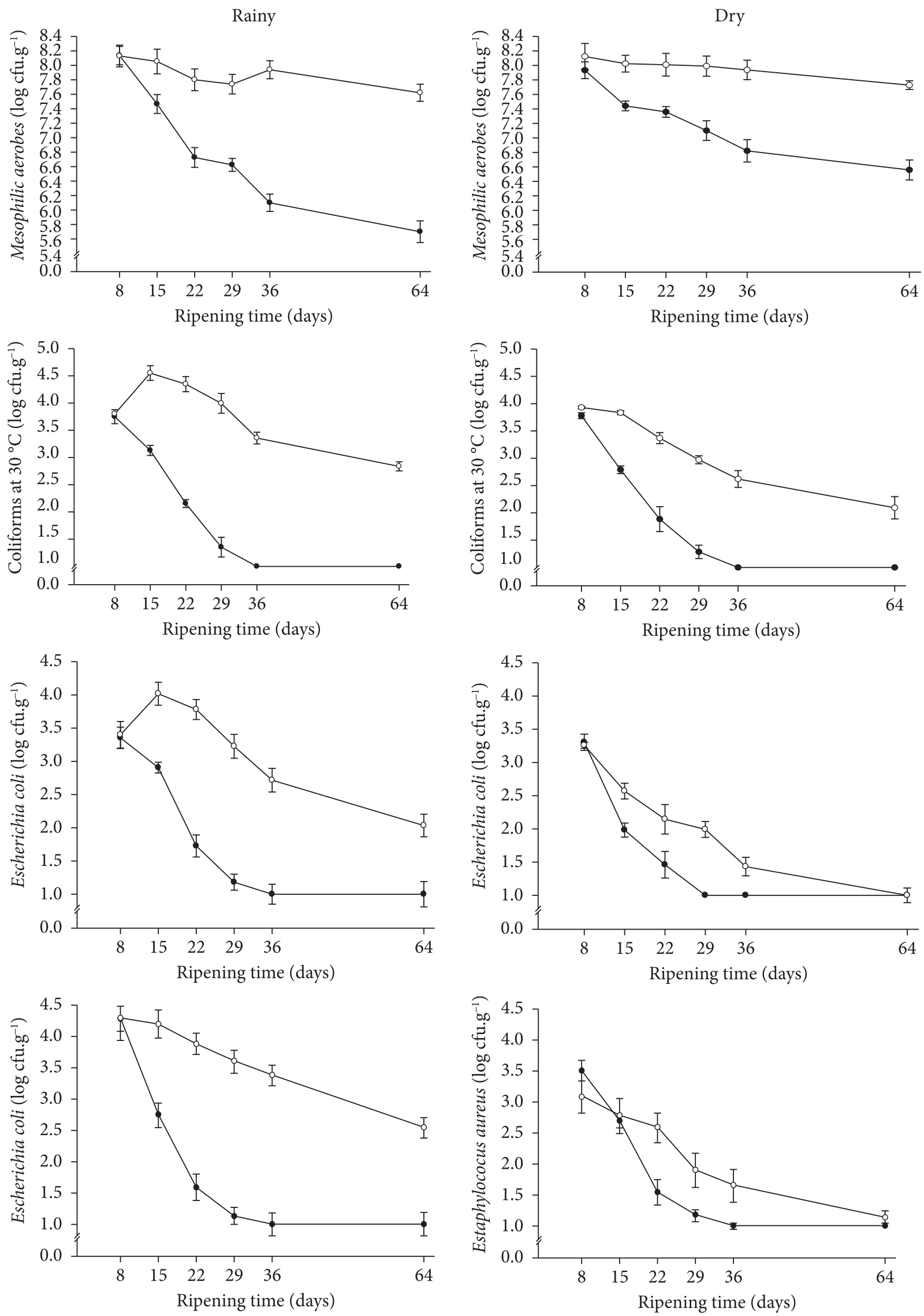

Figure 2. Estimate of counts of mesophilic aerobes, coliforms at $30^{\circ} \mathrm{C}$, Escherichia coli, and Staphylococcus aureus in Canastra cheese as a function of ripening time at room temperature $(\bullet)$ and under refrigeration $(\mathrm{O})$ in the dry season and rainy season. 
At eight days of ripening, all samples of Canastra cheese showed coliform counts at $30^{\circ} \mathrm{C}, E$. coli and $S$. aureus counts higher than those established by the Brazilian legislation. These results may be associated with the absence of heat treatment and improper handling of milk used in the production of such cheeses. Other sources of contamination that can also be mentioned are the low quality of water used in manufacturing and inadequate manufacturing practices by food handlers. However, the reduction of these microorganisms observed during ripening suggests that they could be inhibited by highly competitive lactic acid bacteria which are able to withstand ripening conditions. It is well known that ripening acts as a natural selector, during which lactic acid bacteria normally inhibit pathogens (CARIDI et al., 2003). The rate of reduction in the pathogen counts may also be related to the reduction of water activity, increased $\mathrm{NaCl}$ concentration, and higher ripening temperature. In a study conducted by Nardes (2006), it was found that the higher the maturation temperature, the greater the loss of moisture in cheese leading to a decreased Aw and increased solid concentration, which increases the chloride content. The salt content is one of the factors that directly interfere in the Aw of cheese, following an inverted proportional tendency (FURTADO; LOURENÇO NETO, 1994). Thus, the higher the concentration of salt in the cheese, the lower the water activity of this product (ECK, 1987).

Table 1 shows the period when the collected cheese samples would be fit for consumption, according to the Brazilian laws (BRASIL, 2000). S. aureus was the species that survived longer under the conditions used. Cheeses aged at room temperature were suitable for consumption after 22 days of ripening in both seasons. However, the cheese stored under refrigeration during ripening required at least 35 days of aging in the dry season, whereas in the rainy season, 64 days of aging were not sufficient to reduce the counts of $S$. aureus to acceptable levels.

It is worth to remember that when the cheese samples were kept refrigerated, no change on the Aw values was observed during ripening. This is important because even after 64 days of ripening these samples were considered high moisture

Table 1. Estimated minimum period of Canastra cheese ripening for microbiological adequacy requirements established by Brazilian legislation.

\begin{tabular}{lccc}
\hline \multicolumn{1}{c}{ Counts } & Season & Ripening temperature & Legislation \\
\hline Coliforms at $30^{\circ} \mathrm{C}$ & Wet & Ambient & $\mathbf{1 6}$ days \\
& & Cooling & 35 dias \\
& Dry & Ambient & $\mathbf{2 1}$ days \\
& & Cooling & 13 days \\
E. coli & Wet & Ambient & $\mathbf{2 2}$ days \\
& & Cooling & 32 days \\
& Dry & Ambient & $\mathbf{1 8}$ days \\
S. aureus & & Cooling & 13 days \\
& Wet & Ambient & $\mathbf{2 2}$ days \\
& & Cooling & $>64$ days \\
& Dry & Ambient & $\mathbf{2 1}$ days \\
& & Cooling & 35 days \\
\hline
\end{tabular}

cheese, and therefore they did not meet the law specifications. Thus, the cooling temperature was not sufficient to maintain the microbiological quality of cheese, and it did not reduce the microbial load during ripening. It is known that temperature is a primary factor in food preservation, especially those foods with high nutrient content and high Aw values such as cheese.

Therefore, refrigeration maintains the initial microbiota in foods produced with raw milk and consequently with the potential to for microbial contamination. This fact is usually ignored or not even recognized by business that transport and commercialize cheese made from raw milk. Similar results were also observed by Martins (2006) when analyzing artisanal cheese produced in the Serro region (MG, Brazil).

\section{Conclusion}

The influence of the ripening period on the physicochemical characteristics of the cheeses aged at room temperature significantly influenced the microbiota, with a reduction in the counts of mesophilic aerobes, coliforms at $30{ }^{\circ} \mathrm{C}, \mathrm{E}$. coli and S. aureus. The genus Listeria sp. and Salmonella sp. were not detected in any of the samples. The species $S$. aureus survived longer under conditions above the legal limit and therefore defined the minimum time required for the ripening of these cheeses. Therefore, the ripening temperature was crucial to reducing pathogenic microorganisms regardless of the season that the cheese was produced. On the other hand, the cheeses made in the dry season that were aged under refrigeration only reached the levels established by law after 37 days of ripening, while in the rainy season, 64 days of ripening were not sufficient to reduce the counts of pathogens to levels acceptable by the Brazilian legislation.

The results of this study indicate that aging under refrigeration was not enough to reduce pathogenic microorganisms at levels below the legal limit, producing cheeses after 64 days of ripening with low microbiological quality and low sensory attributes. The use of refrigeration for cheese ripening should be reviewed by government agencies since this type of treatment does not guarantee the microbiological safety of the product.

\section{Acknowledgements}

The authors are grateful for the financial support provided by the Conselho Nacional de Desenvolvimento Científico e Tecnológico (CNPq) and Fundação de Amparo à Pesquisa do Estado de Minas Gerais (FAPEMIG - process nº. CVZ396/06).

\section{References}

BRASIL. Ministério da Agricultura. Portaria no 146, de 7 de março de 1996. Aprova os regulamentos técnicos de identidade e qualidade dos produtos lácteos. Diário Oficial da Republica Federativa do Brasil, Brasília, DF, 11 mar. 1996. Seção 1, p. 3977-3986.

BRASIL. Ministério da Agricultura, Pecuária e Abastecimento. Resolução $\mathrm{n}^{\circ} 7$, de 28 de novembro de 2000. Critérios de funcionamento e de controle da produção de queijarias, para seu relacionamento junto ao serviço de inspeção federal. Diário Oficial da República Federativa do Brasil, Brasília, DF, nov. 2000. 
Disponível em: <http://www.agricultura.gov.br/>. Acesso em: 25 out. 2012.

CARIDI, A. et al. Ripening and seasonal changes in microbial groups and in physic-chemical properties of the ewes' cheese Pecorino del Poro. International Dairy Journal, v. 13, p. 191-200, 2003.

ECK, A. O queijo. Lisboa: Publicações Europa-América, 1987. (Coleção EUROAGRO, Edição n. 137.024/5.141, v. 1).

FURTADO, M. M.; LOURENÇO NETO, J. P. M. Tecnologia de queijos: Manual técnico para a produção industrial de queijos. São Paulo: Editora Dipemar Ltda., 1994.

KONGO, J. M. et al. Characterization of dominant lactic acid bacteria isolated from São Jorge cheese, using biochemical and ribotyping methods. Journal of Applied Microbiology, v. 103, p. 1838-1844, 2007. PMid:17953594. http://dx.doi.org/10.1111/ j.1365-2672.2007.03423.x

KOSIKOWSKI, F. V.; MISTRY, V. V. Cheese and fermented milk foods. 3rd ed. Westport: FV Kosikowski, LLC, 1997. v. 1 e 2.

LANCETTE, G. A.; BENNET, R. W. Staphylococcus aureus and Staphylococcal enterotoxins. In: DOWNES, F. P.; ITO, K. (Eds.). Compendium of methods for the microbiological examination of foods. Washington: APHA, 2001. cap. 39, p. 387-404.

MARTINS, J. M. Características físico-químicas e microbiológicas durante a maturação do queijo Minas Artesanal da região do Serro. 2006. 158 f. Tese (Doutorado em Ciencias dos Alimentos)Universidade Federal de Viçosa, Viçosa, 2006.

MORGAN, F. et al. Survival of Listeria monocytogenes during the manufactures, ripening and storage of soft lactic cheese made from raw goat milk. International Journal of food microbiology, v. 64, p. 217-221, 2001. http://dx.doi.org/10.1016/S0168-1605(00)00452-9
NARDES, R. E. F. et al. Características reológicas do queijo Zamorano com modificações na temperatura de maturação. Revista do Instituto de Laticínios Cândido Tostes, v. 61, p. 29-37, 2006.

PAK, S. et al. Risk factors for L. monocytogenes contamination of dairy products in Switzerland, 1990 - 1999. Preventive Veterinary Medicine, v. 53, p. 55-65, 2002. http://dx.doi.org/10.1016/S01675877(01)00274-4

PEREIRA, D. B. C. et al. Físico-química do leite e derivados: Métodos analíticos. Juiz de Fora: Oficina de Impressão Gráfica e Editora Ltda., 2001. 190 p.

PINTO, M. S. et al. Queijo Minas Artesanal da região do Serro: Avaliação de Staphylococcus aureus e sua enterotoxina. Revista do Instituto de Laticínios Cândido Tostes, n. 336, p. 82-86, 2004.

PINTO, M. S. Efeito da microbiota endógena e da nisina sobre Listeria sp. e Staphylococcus aureus em queijo Minas artesanal do Serro. 2008. $71 \mathrm{f}$. Tese (Doutorado em Ciência e Tecnologia de Alimentos)-Universidade Federal de Viçosa, Viçosa, 2008.

PONSANO, E. H. G. et al. Correlação entre as técnicas de NMP e PETRIFILM EC na determinação de coliformes em leite pasteurizado e queijo tipo mussarela. Revista do Instituto de Laticínios Cândido Tostes, v. 54, n. 316, p. 22-26, 2000.

STATISTICAL ANALISYS SYSTEM INSTITUTE - SAS. SAS/STAT User's Guide. Version 9. Cary: SAS Institute Inc., 2003.

SCHÖELLER, N. P.; INGHAM, S. C. Comparison of the Baird - Parker agar and 3MTM PetrifilmTM rapid S. aureus count plate methods for detection and enumeration of Staphylococcus aureus. Food Microbiology, v. 18, p. 581-587, 2001. http://dx.doi.org/10.1006/ fmic.2001.0432

VITAS, A. L.; AGUADO, V.; GARCIA-JALON, L. Occurrence of Listeria monocytogenes in Fresh and processed foods in Navarra (Spain). International Journal Food Microbiology, v. 90. p. 349-356, 2004. http://dx.doi.org/10.1016/S0168-1605(03)00314-3 